\title{
Feminisasi Kemiskinan dan Daya Lenting Ibu Rumah Tangga di Kota Surabaya
}

\author{
Azizah Alie ${ }^{1}$, Yelly Elanda ${ }^{2}$ \\ Program Studi Sosiologi Universitas Wijaya Kusuma Surabaya ${ }^{1,2}$ \\ Email : yelly.elanda@gmail.com ${ }^{2^{*}}$ \\ ${ }^{*}$ corresponding author
}

\begin{abstract}
Abstrak
Artikel ini membahas kemiskinan struktural pada wanita di kota Surabaya sebab tidak membagikan peluang yang serupa untuk wanita buat memperoleh akses pangkal energi. lbu rumah tangga pada keluarga miskin seakan terencana dimiskinkan tetapi mereka memiliki energi lenting yang dapat membuat keluarganya bertahan di tengah situasi yang serba kekurangan. Riset ini memakai metode kualitatif dengan pendekatan naratif buat mendefinisikan cara pemiskinan ibu rumah tangga pada keluarga miskin di kota Surabaya serta untuk mengambarkan daya lenting ibu rumah tangga pada keluarga miskin supaya mereka sanggup bertahan hidup. Hasil riset ini membuktikan kalau bunda rumah tangga pada keluarga miskin kota Surabaya hadapi feminisasi kekurangan. Bunda rumah tangga keluarga miskin mempunyai sumber daya manusia (SDM) yang terbatas. Mereka tidak diberi peluang buat mengakses pangkal energi di luar yang bisa tingkatkan kapasitasnya. Mereka hadapi bobot dobel dimana mereka tidak bisa meninggalkan profesi domestiknya. Guna memenuhi kebutuhan hidup keluarganya serta menghadapi situasi yang krisis, ibu rumah tangga pada keluarga miskin memiliki daya lenting antara lain merupakan berdagang di depan rumahnya, menghemat pengeluaran, menjual atau menggadaikan benda, mengikuti arisan, serta meminjam uang pada orang sebelah atau kerabat atau perbankan.
\end{abstract}

Kata kunci : energi lenting; ibu rumah tangga pada keluarga miskin; feminisasi kemiskinan

\section{Feminization of Poverty and Resilience of Housewives in Surabaya City}

\begin{abstract}
This study discusses structural poverty among women in Surabaya city because it does not provide equal opportunities for women to get access to resources. Housewives in poor families seem to be deliberately impoverished but they have resilience that can make their families survive in the midst of deprived conditions. This study uses a qualitative method with a narrative approach to describe the process of impoverishment of housewives in poor families in the city of Surabaya and to describe the resilience of housewives to poor families so that they are able to survive. The results of this study indicate that housewives in poor families in the city of Surabaya experience the feminization of poverty. Housewives of poor families have low human resources. They are not given the opportunity to access outside resources that can increase their capacity. They experience a double burden where they are not allowed to leave their domestic work. To meet the needs of their families and face a crisis situation, housewives in poor families have resilience, including selling in front of their homes, saving expenses, selling/pawning goods, participating in social gatherings, and borrowing money from neighbors/relatives/banks.
\end{abstract}

Keywords : resilience; housewives in poor families; feminization of poverty 


\section{LATAR BELAKANG}

Persoalan kemiskinan pada perempuan perlu mendapatkan perhatian dalam pembangunan karena perempuan masuk dalam kategori kelompok rentan. Masalah kemiskinan yang menimpa perempuan adalah persoalan sistemik yang bisa memiliki dampak besar (Utomo \& Haryani, 2019). Data PBB dalam Supeni \& Ika Sari (2011) menyatakan bahwa sepertiga dari masyarakat dunia berada di bawah garis kemiskinan, dan sekitar $70 \%$ adalah perempuan. Dari sudut pandang gender dan kemiskinan, rumah tangga dinilai menjadi salah satu sumber diskriminasi dan subordinasi terhadap perempuan (Noerdin, 2006). Data yang dikeluarkan oleh Sakernas tahun 2011-2014, menyatakan laki-laki memiliki rasio kesempatan kerja lebih tinggi dibandingkan perempuan. Pada tahun 2014 rasio kesempatan kerja laki-laki yaitu $78,3 \%$ dan perempuan hanya $47,1 \%$. Kesempatan perempuan masuk di ranah publik lebih kecil dibandingkan laki-laki sehingga perempuan rawan untuk menjadi pengangguran. Hal ini diperkuat oleh data yang menunjukkan bahwa tingkat pengangguran terbuka perempuan lebih tinggi dibandingkan laki-laki, yaitu 6,26\% dan laki-laki 5,75\%. Angka partisipasi kerja kepala keluarga perempuan menunjukkan bahwa 60,67\% kepala rumah tangga perempuan yang bekerja dari presentase kepala rumah tangga perempuan sebanyak 14,42\%. (Ritonga, 2014). Angka-angka tersebut menunjukkan bahwa perempuan mengalami marginalisasi dan subordinasi.

Angka kemiskinan yang tinggi pada perempuan disebut dengan feminisasi kemiskinan. Feminisasi kemiskinan sebagaimana yang dikemukakan oleh Scott (2019) adalah kegoyahan ekonomi yang dialami oleh perempuan yang ikut menyumbang ekonomi keluarga. Kegoyahan ekonomi merupakan kondisi ekonomi yang rentan terguncang akibat situasi-situasi yang tidak dapat diprediksi sehingga dapat menimbulkan krisis ekonomi dalam keluarga perempuan miskin. Berkaitan dengan hal tersebut Todaro (2000) mengemukakan, bahwa mayoritas kepala rumah tangga berjenis kelamin perempuan memiliki kapasitas yang rendah dalam menghasilkan pendapatan sendiri dan tidak leluasa dalam mengontrol pendapatan suami. Perempuan tidak memiliki kesempatan yang sama untuk memperoleh pendidikan dan pekerjaan yang layak di sektor formal, serta tunjangan-tunjangan sosial dan program-program penciptaan lapangan pekerjaan yang difasilitasi oleh pemerintah.

Surabaya sebagai kota metropolis tidak luput dari masalah kemiskinan. Dari data yang direlease oleh Biro Pusat Statistik (2015) pada tahun 2014 jumlah penduduk miskin di Surabaya mencapai $110.117(19,29 \%)$ rumah tangga $(\mathrm{KK})$ dari seluruh penduduk Surabaya. Kelompok miskin di kota Surabaya berada di 3 kecamatan, yaitu kecamatan Semampir, kecamatan Tambaksari dan kecamatan Simokerto. Di antara 3 kecamatan tersebut, kecamatan Semampir paling tinggi presentase kemiskinannya yaitu sebesar $60,41 \%$ yang tersebar di 5 kelurahan. Kecamatan Tambaksari terdapat $12,47 \%$ keluarga miskin tersebar di 6 kelurahan dan kecamatan Simokerto terdapat 41,82 \% keluarga miskin tersebar di 5 kelurahan.

Kelurahan Wonokusumo adalah salah satu kelurahan yang berada di kecamatan Semampir tepatnya di Surabaya utara. Setiap tahun pelaku urbanisasi banyak yang datang ke daerah ini. Data BPS menunjukkan bahwa terjadi peningkatan jumlah migran di kecamatan Semampir dari tahun 2011 sampai dengan 2015. Secara presentase peningkatan jumlah pelaku migran atau urbanisasi sebanyak 3,70\% (Riyanta \& Murtedjo, 2019). Meningkatkanya pelaku urbanisasi berdampak pada munculnya pemukiman kumuh (Darma \& Khambali, 2013). Pemukiman di kelurahan Wonokusumo

$$
\text { Jurnal Sosiologi Pendidikan Humanis } 199 \text { | } 215
$$


sangat padat, berjejal, terlihat kumuh karena sampah banyak dibuang di selokan sehingga pada musim hujan, biasanya akan terjadi banjir. Penduduk pendatang mayoritas bermata pencaharian sebagai PKL, buruh dan tukang. Sekitar 60-70\% dari jumlah penduduk di kelurahan Wonokusumo tergolong miskin. Mereka banyak bekerja di sekor informal sehingga tidak dapat mencukupi kebutuhan hidupnya (Profil Wonosari Wetan Kelurahan Wonokusumo, n.d.).

Berdasarkan hasil penelitian yang dilakukan oleh Setijaningrum, kelurahan Wonokusumo dihuni oleh $2736 \mathrm{KK}$ yang berasal dari Madura dan sudah menetap selama puluhan tahun di kelurahan Wonokusumo. Kondisi pemukimannya kumuh terutama di RW 4 karena bangunannya masih berupa gubuk atau barak. Daerah di RW 6 juga sangat kumuh karena dekat dengan pasar Wonokusumo. MCK masih menggunakan drainase sungai dan masyarakat di sini juga rentan terhadap penyakit karena kondisi rumah dan lingkungan yang tidak layak huni (Setijaningrum, 2012). Keluarga miskin di kelurahan Wonokusumo ini tidak memiliki latar belakang pendidikan dan keterampilan yang cukup sehingga mereka bekerja serabutan, dan cenderung tidak bisa mencari pekerjaan alternatif (Butar \& Setiawan, 2012). Kepala keluarga atau suami bekerja sebagai kuli bangunan, tukang becak atau buruh harian lepas tidak mampu mencukupi kebutuhan keluarga sehingga mendorong perempuan miskin untuk mencari penghasilan dengan berjualan di depan rumah, berjualan ke pasar, menjadi buruh cuci, ART dan pekerjaan lain di sektor informal.

Tingkat pendidikan perempuan (ibu rumah tangga) miskin ini juga tergolong rendah sehingga mereka hanya bisa bekerja di rumah dan tidak mampu bekerja di luar rumah (Ariadi \& Suyanto, 2009). Ibu-ibu dari keluarga miskin dibebani dengan kewajiban sosial untuk menjalankan tugas domestiknya sehingga hanya sedikit perempuan (ibu) yang bekerja di luar rumah. Biasanya mereka bekerja di depan rumah membuka usaha sendiri sambil mengurusi pekerjaan domestiknya. Kondisi ini menyebabkan perempuan mengalami beban ganda. Terlebih ibu-ibu miskin ini tinggal di wilayah urban dengan ketidakberdayaan hidup di bawah tekanan kemiskinan, keterisolasian, ketidakadilan gender membuat posisi perempuan semakin rapuh dan rentan (Ariadi \& Suyanto, 2009). Penelitian ini bertujuan untuk mendeskripsikan kondisi sosial ekonomi perempuan khususnya ibu rumah tangga pada keluarga miskin dan proses pemiskinan atau feminisasi kemiskinan pada ibu rumah tangga keluarga miskin. Selain itu, penelitian ini juga mengungkap bagaimana daya lenting ibu rumah tangga pada keluarga miskin untuk mempertahankan kehidupan keluarganya.

\section{METODE PENELITIAN}

Penelitian ini menggunakan jenis penelitian kualitatif dengan pendekatan naratif, bertujuan untuk mendeskripsikan setting lokasi dan subjek yaitu perempuan (ibu) pada keluarga miskin di kelurahan Wonokusumo kecamatan Semampir kota Surabaya. Penelitian ini menggunakan jenis penelitian kualitatif dengan pendekatan naratif. Jenis penelitian ini merupakan srategi penelitian yang dilakukan oleh peneliti untuk menyelidiki kehidupan individu-individu dengan cara meminta mereka untuk menceritakan kehidupannya (Creswell, 2017). Dalam penelitian ini, peneliti meminta kepada ibu-ibu rumah tangga untuk menceritakan kondisi sosial ekonominya di tengah kemiskinan yang menderanya. Peneliti juga berusaha untuk mencari tahu tentang strategi yang dilakukan oleh ibu-ibu rumah tangga dalam keluarga miskin agar mampu bertahan hidup dan keluar dari jerat kemiskinan. Peneliti melakukan wawancara dengan 11 informan dan 
menggunakan tehnik purposive dalam penentuan informan yang akan diwawacarai. Peneliti sengaja memilih informan dengan kriteria yang telah ditetapkan yakni ibu rumah tangga yang keluarganya termasuk dalam kategori miskin dan tinggal di kelurahan Wonokusumo kecamatan Semampir kota Surabaya. Selain melakukan wawancara, peneliti juga melakukan observasi untuk mendapatkan informasi dengan cara mengamati kondisi rumah dan lingkungan yang mereka tinggali.

Peneliti memilih lokasi penelitian di kelurahan Wonokusumo kecamatan Semampir kota Surabaya karena berdasarkan data BPS kota Surabaya tahun 2017, kecamatan Semampir merupakan kecamatan yang tingkat kemiskinannya tertinggi di kota Surabaya. Jumlah penduduk miskin dari tahun 2014 hingga 2016 semakin meningkat mulai tahun 2014 sebanyak 10.093, 12.789 di tahun 2015 dan 13.264 pada tahun 2016 (Elviani, 2017). Kecamatan ini merupakan kantong kemiskinan dan banyak dihuni oleh pelaku migran dan masyarakat marginal. Secara lokasi, kecamatan Semampir ini dekat dengan Pelabuhan Tanjung Perak dan dekat dengan pulau madura sehingga banyak dihuni oleh masyarakat madura yang melakukan urbanisasi. Mereka tinggal di lingkungan kumuh dan berbaur dengan masyarakat miskin kota lainnya. Mereka cenderung tidak memiliki KTP atau identitas yang sah sehingga tidak mendapatkan hakhak sebagai warga kota Surabaya. Kemiskinan yang terjadi di kelurahan Wonokusumo kecamatan Semampir adalah masalah kemiskinan yang saling tumpang tindih akibat adanya over urbanization (urbanisasi berlebih). Posisi perempuan dalam keluarga miskin menjadi semakin rentan dan teropresi akibat kemiskinan yang membelenggunya dan akibat budaya patriarkhi yang menempatkannya sebagai kelas kedua, karena masyarakat yang tinggal di sana mayoritas bersuku madura dan jawa

\section{HASIL DAN PEMBAHASAN \\ Kemiskinan Di Perkotaan}

Masalah kemiskinan adalah masalah yang sudah lama dihadapi oleh manusia bahkan sama tuanya dengan umur manusia. Kemiskinan menjadi tema yang selalu menarik dan tidak pernah usai untuk dibahas. Banyak penelitian, pengamatan dan solusi yang diberikan untuk mengentaskan masyarakat dari kemiskinan. Namun pada kenyataannya, kemiskinan tidak pernah hilang dari muka bumi ini. Setiap masa memiliki indikator dan karakteristik yang berbeda untuk menentukan orang tersebut dinyatakan sebagai miskin. Dari sudut pandang ekonomi, kemiskinan identik dengan kondisi keluarga yang tidak mampu memenuhi kebutuhan primernya seperti pendidikan, kesehatan, sandang, pangan dan papan. Namun secara sosial dan budaya, kemiskinan juga bisa timbul akibat adanya nilai-nilai kultural yang melanggengkan kemiskinan (Suryawati, 2005). Kemiskinan juga bisa berkaitan dengan kebudayaan, hal ini disebut sebagai budaya kemiskinan (Rachmawati, 2011).

Budaya kemiskinan merupakan suatu pola perilaku dan sikap yang ditunjukkan oleh masyarakat kelas bawah untuk mempertahankan kelangsungan hidupnya di tengah situasi yang serba kekurangan. Cara hidup inilah yang menjadi landasan terbentuknya budaya miskin. Mekanisme survival ini yang disosialisasikan secara terus menerus dari orang tua kepada anaknya sehingga menjadi budaya. Mengharapkan sedekah, meminta-minta dan menerima nasib menjadi salah satu budaya dari keluarga miskin

agar bertahan hidup. Dengan demikian menurut Oscar Lewis, solusi untuk memerangi kemiskinan adalah dengan merubah kebudayaan tersebut (Suparlan dalam Trisnawaty, 2018). Kemiskinan dianggap sebagai budaya selalu dikaitkan dengan etos kerja dan

$$
\text { Jurnal Sosiologi Pendidikan Humanis 201 | } 215
$$


cara hidup masyarakat sehingga membentuk streotipe dalam kelompok masyarakat tertentu (Soetrisno dalam Rasna \& Hidaya, 2019).

Kemiskinan juga bisa disebabkan oleh struktural yang berkenaan dengan faktorfaktor penyebab terjadinya kemiskinan akibat ulah manusia itu sendiri, diantaranya adalah kebijakan yang dapat menimbulkan ketidakadilan dalam penguasaan faktor produksi, menganut sistem ekonomi dunia tertentu yang hanya menguntungkan sekelompok orang saja, adanya tindak korupsi dan kolusi serta ketidakmerataan distribusi asset produksi (Asyifani, 2021). Pandangan yang ketiga tentang kemiskinan dilihat dari kualitas sumber daya manusia yang rendah dan keterbatasan sumber daya alam yang dimiliki (Asyifani, 2021). Penyebab terjadinya kemiskinan tidak hanya disebabkan oleh salah satu faktor saja, baik secara ekonomi, sosial dan budaya, struktural maupun kualitas SDM dan kepemilikan SDA. Dalam kenyataannya kemiskinan terjadi karena banyak faktor yang mempengaruhinya. Memahami dan mengamati kemiskinan harus lebih kompleks dan utuh, tidak hanya dari satu faktor saja. Robert Chambers menggunakan konsep kemiskinan terpadu untuk memahami kemiskinan. Terdapat lima unsur yang melingkupi kehidupan masyarakat miskin dan menjadi perangkap kemiskinan, diantaranya adalah (1) kemiskinan; (2) fisik yang lemah; (3) kerentanan; (4) keterisolasian; (5) ketidakberdayaan (Subair, 2012).

Kelima faktor ini yang akan menjelaskan bagaimana kehidupan masyarakat miskin menjadi perangkap bagi dirinya dan sulit keluar dari kemiskinan. Setiap lokus memiliki konteksnya sehingga kemiskinan tidak bisa digeneralisir. Kemiskinan masyarakat yang hidup di perkotaan berbeda dengan masyarakat pedesaan (Ikawati dan Wahyuni, 2016). Penelitian ini lebih memilih fokus di daerah perkotaan karena kota merupakan pusat industri, pembangunan dan dekat dengan pemerintahan. Seharusnya kota bisa menampung semua kebutuhan para pendatang dan penduduknya. Kota bisa memberikan berbagai macam alternatif untuk memperoleh pekerjaan sesuai dengan kemampuan dan keahlian. Namun pada kenyataannya kemiskinan di perkotaan justru semakin meningkat. Hasil penelitian menunjukkan bahwa penduduk miskin di perkotaan semakin meningkat dari 18,45\% di tahun 1976 menjadi 36,61\% pada 2009 (Lembaga Penelitian Smeru Reseach Institute, 2012). Peningkatan jumlah penduduk miskin ini berbanding lurus dengan peningkatan jumlah penduduk di wilayah perkotaan. Pertumbuhan populasi perkotaan di Indonesia sebesar 3, 85\% dari tahun 1980 hingga 2010 dan ini membuat proporsi penduduk perkotaan meningkat dari $22,10 \%$ pada tahun 1980 menjadi 44, 28\% di tahun 2010 (Lembaga Penelitian Smeru Reseach Institute, 2012).

Peningkatan jumlah penduduk miskin di perkotaan tetap ada karena potensipotensi yang ada (lingkungan fisik/sumber daya alam, sistem sosial dan kebudayaan) tidak atau belum dapat dimanfaatkan oleh para pelaku urbanisasi (Suparlan, 1984). Pelaku urbanisasi seharusnya datang ke kota dengan membawa modal yang cukup baik secara kualitas SDM maupun kepemilikan modal secara ekonomi. Dengan tingkat pendidikan yang rendah, terbatasnya keterampilan yang dimiliki dan kurang memiliki modal secara ekonomi maka perantau di kota hanya akan menjadi pengangguran dan semakin memperbesar komposisi orang miskin di perkotaan. Selain itu, penyebab terjadinya peningkatan angka kemiskinan di perkotaan adalah kebudayaan masyarakat kota dan desa yang berbeda, berkenaan dengan cara hidup atau sistem mata pencaharian. Kemampuan adaptasi dari para perantau yang datang dari desa dengan sistem ekonomi yang menekankan pada penghasilan dari bahan mentah dan bahan 
makanan atau hasil bumi/pertanian ke sistem ekonomi di perkotaan yang mengandalkan keahlian dan kemampuan dalam mendapatkan pekerjaan (Suparlan, 1984). Urbanisasi sejatinya adalah perpindahan penduduk dari desa ke kota namun pada kenyataannya perpindahan ini cenderung diikuti dengan urbanisasi kemiskinan. Urbanisasi kemiskinan ini juga berdampak pada masalah perkotaan seperti aspek ekologis (banjir dan pencemaran lingkungan), aspek fisik (infrastruktur dan transportasi), dan aspek non fisik (kesenjangan, ketidakadilan, keterbatasan lapangan pekerjaan) (Lembaga Penelitian Smeru Reseach Institute, 2012).

Surabaya merupakan kota terbesar kedua di Indonesia dan merupakan ibukota Jawa Timur sehingga menjadi pusat pemerintahan, pertumbuhan ekonomi, perdagangan, industri dan jasa. Tidak heran jika banyak masyarakat desa atau dari kota lain datang untuk mengadu nasib atau mencari penghidupan di Surabaya. Masyarakat desa yang miskin datang ke kota membentuk kampung kumuh di kota dan tinggal secara berkelompok. Menurut Jellinek para perantau ini hidup bersama, saling tolong menolong dan menciptakan ikatan sosial yang kuat diantara mereka (Jellinek, 1995). Kondisi ini menyebabkan kota Surabaya mengalami masalah urbanisasi berlebih atau disebut dengan over urbanization (Ariadi \& Suyanto, 2009). Kecamatan Semampir merupakan salah satu kecamatan yang selama ini selalu menempati peringkat teratas dalam jumlah penduduk miskin. Kecamatan Semampir menjadi wilayah kantong kemiskinan karena dihuni banyak dihuni oleh para pelaku urbanisasi yang berasal dari pulau madura. Letaknya yang dekat dengan jembatan Suramadu (penghubung Surabaya dan madura) menjadi salah satu alasan mereka tinggal di sana. Selain itu alasan yang kedua adalah, lokasi ini dekat dengan Pelabuhan Tanjung Perak yang menjadi sentra pengembangan aktivitas ekonomi sehingga para pelaku urbanisasi berharap mendapatkan pekerjaan dan penghasilan di sana. Banyaknya para pelaku urbanisasi atau migran menyebabkan lingkungan daerah tersebut menjadi kumuh karena mereka mendirikan rumah "seadanya" bahkan membentuk perkampungan jembel atau disebut dengan slum (Suparlan dalam Basir, 2012). Mereka membentuk perumahan kumuh dan liar sebagai tempat berteduh. Terdapat bangunan rumah yang disewakan maupun dihuni sendiri di daerah slum tersebut. mereka menyewa dengan harga yang murah karena perumahan tersebut jauh dari kata layak huni, fasilitas air bersih dan sanitasi serta sirkulasi udara tidak bisa mereka dapatkan. Bahkan seringkali mereka menjadi kelompok yang rawan untuk digusur karena menempati wilayah yang bukan menjadi hak miliknya.

\section{Feminisasi Kemiskinan di Kota Surabaya}

Data BPS tahun 2018 menunjukkan tingkat partisipasi angkatan kerja perempuan lebih rendah dibandingkan laki-laki, tingkat partisipasi angkatan kerja perempuan hanya $51,88 \%$ dan laki-laki $82.69 \%$. Namun jumlah pengangguran terbuka lebih tinggi laki-laki dibandingkan perempuan, laki-laki 5,40\% dan perempuan 5, 26\% (Badan Pusat Statistik, 2018). Hal ini menjadi menarik jika diamati bahwa tingkat partisipasi angkatan kerja perempuan lebih rendah namun pengangguran terbuka perempuan juga lebih rendah dibandingkan laki-laki. Lalu perempuan berada di sektor mana dalam hal pekerjaan? Ternyata data menunjukkan perempuan banyak bekerja di sektor informal sebanyak $61,80 \%$. Mayoritas perempuan bekerja di tiga bidang utama yakni pertanian, kehutanan dan perikanan. Rata-rata penghasilan yang didapat oleh perempuan berada di angka 2, 39 juta, lebih rendah dibandingkan laki-laki yang berkisar pada angka 3, 06 juta (Badan Pusat Statistik, 2018). 
Data di atas menunjukkan adanya ketimpangan, ketidakadilan dan diskriminasi terhadap perempuan dimana mereka mengalami beban ganda atau double bourden dengan mengungkung perempuan dalam kehidupan domestik, formal dan informal sehingga kehadirannya dianggap memiliki kontribusi yang minim dengan pendapatan yang rendah serta rentan resiko. Pekerjaan di bidang pertanian, kehutanan dan perikanan merupakan pekerjaan yang telah menjadi satu dengan ranah domestik sebagaimana masyarakat komunal dulu. Perempuan masih belum diberikan kesempatan yang sama di sektor formal. Gaji yang diterima atau pendapatan yang didapat perempuan lebih rendah dibandingkan laki-laki karena perempuan masih menempati posisi yang kurang strategis dalam pekerjaan. Perempuan menjadi tidak berdaya menghadapi lingkungan yang masih diselimuti oleh budaya patriarkhi.

Dalam dari kementerian pemberdayaan perempuan dan perlindungan anak menunjukkan bahwa 20 tahun terakhir, tingkat partisipasi Angkatan kerja laki-laki dan perempuan cenderung stagnan. Laki-laki hanya berkisar di $84 \%$ dan perempuan berkisar 50\% (Kementrian Pemberdayaan Perempuan dan Perlindungan Anak, 2019). Banyaknya jumlah partisipasi angakatan kerja laki-laki dipengaruhi oleh pembagian tugas kerja dalam rumah tangga berdasarkan gender dimana laki-laki berperan sebagai pencari nafkah utama keluarga dan perempuan berkutat di sektor domestik. Faktor penyebab lainnya adalah kurangnya informasi, diskriminasi gender dan biaya yang tinggi. Peran perempuan di sektor informal dianggap sebagai pekerjaan sampingan, berupah minim bahkan tidak diberi upah dan bentuk perlindungannya tidak ada (Kementrian Pemberdayaan Perempuan dan Perlindungan Anak, 2019). Hal ini turut menyumbangkan jumlah perempuan miskin atau ibu rumah tangga pada keluarga miskin terus terperangkap dalam lingkaran setan kemiskinan.

Membahas kemiskinan perempuan tidak bisa melihat hanya dari kacamata ekonomi saja, namun juga dari segi sosial dan politik yang berkaitan dengan karakteristik tertentu. Kemiskinan perempuan menjadi begitu kompleks untuk dibahas karena kelompok perempuan tersebut tidak hanya mengalami kemiskinan namun juga ketidakadilan, ketidakberdayaan dan diskriminasi gender yang membuatnya sulit terlepas dari jerat kemiskinan. Kemiskinan perempuan terpusat pada perempuan yang menjadi kepala rumah tangga dan pendapatannya lebih rendah dibandingkan dengan laki-laki (Sach, 2005). Perspektif feminism sosialis melihat proses pemiskinan perempuan terjadi karena konstruksi sosial yang bias gender dan hal ini menyebabkan perempuan teropresi dan tersubordinasi (Rustanto, 2015). Dalam sejarah manusia yang panjang, perempuan menjadi kelas kedua, tersubordinasi oleh laki-laki demi kelangsungan penguasaan mode produksi dalam sistem kapitalis (Nes dan Ladicola dalam Rustanto, 2015). Pada lingkungan keluarga, perempuan diubah dari orang yang independen (bebas) dan setara (equal) menjadi orang yang bergantung dan tersubordinasi. Keluarga menjadi lembaga yang memeras dan melanggengkan ideologi patriarkhi (Fakih, 2016).

Feminisasi kemiskinan mendeskripsikan kondisi perempuan yang mengalami ketidakberdayaan atau kegoyahan secara ekonomi untuk menyokong kehidupan keluarganya (Ollenburger \& Moore, 2002). Kemiskinan berwajah perempuan merupakan kondisi perempuan baik yang berperan sebagai kepala rumah tangga maupun perempuan dalam keluarga miskin yang berperan ganda di ranah domestik dan publik untuk memenuhi kebutuhan keluarganya (Utamaningsih, 2020). Pengertian lain menyebutkan bahwa feminisasi kemiskinan merupakan ketidakberuntungan perempuan 
atas hak-haknya yang diakibatkan oleh bias gender dan kemiskinan dalam masyarakat. bias gender ini telah menyebabkan perempuan menjadi penyumbang besar dari ketidakberuntungan ekonomi (Pearce dalam Utamaningsih, 2020).

Pada dasarnya perempuan mampu memberikan kontribusi lebih besar pada perekonomian. Perempuan hanya harus diberikan kesempatan yang sama baik di bidang pendidikan untuk mengasah keterampilan dan pengetahuannya dan dalam ranah pekerjaan. Tingkat partisipasi angkatan perempuan harus ditingkatkan agar perempuan mampu berperan dalam pembangunan (Kementrian Pemberdayaan Perempuan dan Perlindungan Anak, 2019). Perempuan harus diberikan akses pada sumber daya, tidak membebankan tugas domestik hanya pada perempuan dan didorong untuk ke ranah publik serta mendapatkan gaji dan pekerjaan yang layak. Kesetaraan gender menjadi penting untuk dipahami agar keluarga miskin juga bisa keluar dari perangkap kemiskinan.

Keluarga miskin di kota Surabaya banyak bekerja di sektor informal dan mereka tidak memiliki keahlian yang cukup untuk mendapatkan pekerjaan formal. Tingkat Pendidikan mereka juga rendah yakni berkisar lulus SD dan SMP. Mayoritas mereka adalah pelaku urbanisasi yang mengadu nasib ke kota namun tidak diimbangi oleh skill. Mereka hidup di daerah kumuh yang merupakan kantong kemiskinan. Pemukiman kumuh menurut Budiharjo dalam Istikasari dan Khadiyanto (2014) digambarkan sebagai pemukiman yang dihuni oleh orang yang berasal dari desa miskin, bekerja di sektor informal dan belum memiliki fasilitas elementer yang baik dan rumah tersebut belum memenuhi standar kesehatan yang baik. Keluarga perempuan miskin di kota Surabaya mendiami rumah dengan ukuran yang sangat sempit dan jauh dari kata layak. Lingkungan yang berdesakan dan jauh dari kata bersih bahkan untuk mendapatkan air saja mereka harus berbagi sumur dengan rumah tangga yang lain, akses air bersih sulit. Mereka rela hidup di tempat demikian karena berkenaan dengan harga sewa rumah. Mereka tidak sanggup membayar sewa di atas jumlah penghasilannya, mereka juga harus memenuhi kebutuhan lainnya.

Mayoritas laki-laki atau suami atau kepala keluarga bekerja di sektor informal sebagai tukang bangunan, tukang parkir dan serabutan. Pendapatan yang tidak menentu membuat ibu rumah tangga pada keluarga miskin ini memutar otak dan berusaha untuk mendapatkan penghasilan tambahan bagi keluarga (Ariadi \& Suyanto, 2009). Ibu rumah tangga pada keluarga miskin di kota Surabaya juga turut bekerja membantu suami untuk mencukupi kebutuhan keluarga. Mereka banyak bekerja di sektor informal karena mereka terikat oleh beban domestik dimana harus menjaga anak bahkan cucu. Mayoritas ibu rumah tangga keluarga miskin memilih untuk bekerja di sekitar rumahnya sebagai penjual gorengan di depan rumah, buruh cuci, penjaga toko, ART dan pelayan warung. Mereka tidak bisa bekerja di sektor formal karena mereka tidak memiliki waktu luang untuk bekerja di publik. Mereka dibebani dengan pekerjaan domestik yang pekerjaannya cukup menyita waktu. Selain itu, mereka juga memiliki tingkat pendidikan yang rendah sehingga tidak bisa mengakses pekerjaan yang layak. Ibu rumah tangga dalam keluarga miskin di kota Surabaya mengalami ketidakberdayaan, marginalisasi, ketidakadilan, beban ganda dan subordinasi.

\section{Kondisi Sosial Ekonomi lbu Rumah Tangga Miskin}

Kemiskinan yang terjadi di perkotaan adalah suatu kondisi yang menunjukkan ketidakmampuan seseorang dalam memenuhi hak-hak dasarnya. Menurut Rustanto, 
masyarakat miskin adalah masyarakat yang terpinggirkan atau kaum marginal yang mengalami deprivasi dalam memenuhi kebutuhannya, tidak memiliki akses terhadap sumber daya yang ada di sekitarnya. Hal ini terjadi dikarenakan diskriminasi dan keterasingan sosial (Rustanto, 2015). Seseorang atau keluarga miskin memiliki ruang gerak terbatas atau terbatas, cenderung tidak berdaya, rentan terhadap resiko dan sulit untuk terserap dalam usaha-usaha yang memungkinkan mereka bisa berkembang (Ariadi \& Suyanto, 2009). Kondisi sosial ekonomi ibu rumah tangga pada keluarga miskin di kota Surabaya dapat dikategorikan melalui tingkat pendidikan, kepemilikan rumah, penghasilan/pekerjaan dan keterlibatan ibu rumah tangga dalam kegiatan sosial, agama dan politik di daerah tempat tinggalnya.

\section{Kepemilikan Rumah}

Keluarga miskin yang tinggal di kota Surabaya dan berada di daerah slum adalah rumah yang dimiliki oleh orang tua mereka bahkan ada beberapa yang tinggal di bersama dengan keluarga lain atau tinggal bersama keluarga besar. Satu rumah bisa dihuni 2 keluarga yang terdiri dari 5- 8 orang. Mayoritas rumah yang didiami oleh ibu rumah tangga keluarga miskin adalah rumah milik orang tua suami maupun orang tuanya. Rumah yang berhimpitan dengan tetangga-tetangganya bahkan hanya berbatas satu tembok dengan ukuran rumah yang cukup sempit, ventilasi udara untuk mendapatkan sirkulasi udara di dalam rumah agar baik tidak ada. Jendela rumah hanya terdapat di ruang tamu atau depan rumah, selebihnya tidak ada ventilasi udara maupun jendela karena rumah mereka terkepung dengan rumah tetangga yang lain. Ruang makan bercampur dengan ruang tamu, dapur dan ruang televisi atau keluarga. Secara struktur bangunan, rumah tersebut tidak layak huni, bahkan bagian sentral dari rumah yakni toilet dan sanitasi tidak bisa mereka dapatkan. Mereka mengandalkan air bersih dan toilet umum yang disediakan oleh pemerintah. Terdapat toilet umum dan sumur yang ada di dekat perkampungan mereka. Biasanya mereka antri untuk melakukan mandi, cuci baju dll. Ada beberapa rumah yang masih memiliki toilet namun air yang mereka dapatkan tidak bersih, mereka harus mengambil ke sumur umum untuk mendapatkan air bersih untuk masak.

Dari 11 informan yang diwawancarai terdapat 2 orang yang mendiami rumah kontrakan. Mereka mengontrak rumah dengan harga yang murah. Rumah yang mereka tidak terlihat seperti rumah karena ruangan itu sempit dan hanya disekat menjadi beberapa ruangan dengan menggunakan kelambu. Mereka terpaksa memilih sewa rumah di sana karena harganya yang murah dan dekat dengan lokasi mereka kerja. Selain itu, kawasan perkampungan di Surabaya utara tersebut banyak dihuni oleh suku madura sehingga mereka merasa seperti tinggal di kampung halamannya sebagai saudara karena suku yang sama.

\section{Tingkat Pendidikan}

Para ibu rumah tangga pada keluarga miskin yang ada di kota Surabaya memiliki tingkat pendidikan yang cukup rendah, bahkan mereka tidak menuntaskan wajib belajar yang dicanangkan oleh pemerintah selama 12 tahun. Mayoritas ibu rumah tangga miskin mengeyam pendidikan hanya sampai pada sekolah dasar, hanya ada beberapa yang mampu menuntaskan pendidikan setingkat sekolah menengah pertama (SMP). Berdasarkan hasil wawancara kepada 11 informan, tingkat pendidikan ibu rumah tangga miskin, paling tinggi hanya lulus SMP dan itu hanya ada 2 orang dari 11 orang yang diwawancarai. Mereka tidak dapat melanjutkan sekolah ke jenjang yang lebih tinggi 
karena terkendala oleh biaya. Mereka juga tidak mengikuti kursus atau pelatihan untuk mengasah keterampilannya. Mereka tidak mendapatkan bantuan biaya dan harus bekerja untuk membantu orang tua mereka mendapatkan penghasilan. Hal ini menyebabkan mereka harus putus sekolah dan menikah di usia yang cukup muda yakni sekitar 17 tahun atau 18 tahun agar mereka tidak menjadi beban keluarga.

Dengan menikah diharapkan orang tua tidak lagi menanggung beban hidup anak perempuan dan menjadi tanggung jawab suaminya. Namun cara ini justru membentuk keluarga miskin baru. Ibu rumah tangga miskin yang berpendidikan rendah, tidak memiliki keahlian atau keterampilan terjebak dalam kemiskinan baru di lingkungan keluarganya. Mereka tidak bisa mengakses pekerjaan yang memiliki tingkat keamanan, kerentanan yang memadai dan bisa membuat mereka berkembang. Mereka hanya bisa bekerja di sektor yang rentan, tidak bisa mendapatkan jaminan atau asuransi jika terjadi kecelakaan maupun kondisi darurat. Hal ini juga berimplikasi terhadap jumlah penghasilan yang diperoleh.

\section{Penghasilan/Pekerjaan}

Mayoritas ibu rumah tangga pada keluarga miskin bekerja di sektor informal. Mereka bekerja sebagai penjual gorengan, bubur, minuman, makanan ringan atau snack, penjaga toko, pencuci baju dan ART (Asisten Rumah Tangga). Namun ada beberapa informan yang hanya sebagai ibu rumah tangga saja. Ibu rumah tangga yang hanya mengurus keluarga saja, tidak bisa bekerja, biasanya dikarenakan tugas domestik yang harus diembannya. Misalnya, mereka harus mengurus dan menjaga bayi dari anaknya atau cucunya atau mereka baru saja memiliki bayi yang harus mereka jaga.

Para ibu rumah tangga yang bekerja didorong oleh keinginan untuk mendapatkan penghasilan tambahan. Para suami sebagai kepala keluarga memiliki penghasilan yang tidak menentu, kalaupun ada yang memiliki pekerjaan tetap, penghasilannya tidak mencukupi kebutuhan keluarga. Para suami pada keluarga miskin, mayoritas bekerja sebagai kuli bangunan dan serabutan. Ada juga yang memiliki pekerjaan tetap sebagai petugas kebersihan, penghasilannya Rp. 1.500.000. Dengan kondisi demikian maka para ibu rumah tangga berinisiatif untuk membuka usaha. Mereka berjualan makanan berupa gorengan, makanan ringan, minuman dan bubur.

Para ibu rumah tangga memilih untuk menjual makanan dan minuman karena modal usaha yang diperlukan tidak terlalu banyak dan perputaran uang realtif cepat. Banyaknya penjual gorengan, hampir di setiap deret perumahan bahkan terdapat beberapa penjual gorengan pada setiap deret perumahan menyebabkan persaingan makin kuat. Perbandingan jumlah pembeli dan penjual menjadi semakin kecil dan penghasilan yang diterima oleh ibu rumah tangga juga makin kecil. Persaingan penjual gorengan makin sengit, banyak ibu rumah tangga miskin yang menjual gorengan bisa dikatakan bahwa mereka tidak memiliki inovasi, keahlian dan keterampilan membuat produk. Seharusnya para ibu rumah tangga ini membuat inisiatif produk lain yang berbeda, tidak hanya sekedar gorengan. Seharusnya mereka membentuk suatu kelompok ibu-ibu yang bisa melakukan kegiatan produktif atau program pemberdayaan untuk meningkatkan penghasilan.

\section{Keterlibatan Ibu Rumah Tangga dalam Kegiatan Sosial, Politik dan Agama}

Ikatan solidaritas yang terjalin diantara ibu-ibu rumah tangga keluarga miskin dinilai cukup kuat. Hal ini dikarenakan keluarga miskin memiliki norma yang mengatur hubungan diantara mereka dan adanya kekuatan untuk saling mendukung terutama

$$
\text { Jurnal Sosiologi Pendidikan Humanis 207 | } 215
$$


untuk mencapai keberhasilan ekonomi. Menurut Putnam, jaringan sosial, kerjasama dan kepercayaan merupakan wujud dari modal sosial suatu kelompok dalam membangun ekonomi (Syahra, 2003). Ibu-ibu rumah tangga keluarga miskin saling membantu dalam keadaan susah maupun senang. Bagi mereka, tetangga merupakan saudara terdekat yang bisa diminta pertolongannya. Oleh karena itu kegiatan sosial yang ada pada perkampungan tersebut terlihat aktif, seperti saat ada kematian maka para tetangga tolong menolong untuk membantu, saat ada yang sakit maka mereka datang untuk menjenguk dan memberikan bantuan. Begitupun jika ada acara nikahan maka para tetangga juga datang untuk melakukan rewang. Kegiatan sosial lain yang diikuti oleh para ibu rumah tangga adalah kegiatan PKK. Mereka banyak mengikuti kegiatan ini agar hubungan diantara warga kampung menjadi erat, saling mengenal dan bisa akrab dengan warga. Kegiatan sosial ini hanya dijadikan sebagai ajang silaturahmi, tidak ada kegiatan pemberdayaan bagi perempuan khususnya ibu rumah tangga. Ibu rumah tangga pada keluarga miskin tidak diberikan informasi atau akses untuk mendapatkan bantuan melalui kegiatan ini. Hal ini juga terjadi pada kegiatan-kegiatan lain yang diikuti oleh ibu-ibu rumah tangga pada keluarga miskin.

Terdapat kegiatan agama yang diikuti oleh keluarga miskin di kelurahan Wonokusumo kecamatan Semampir Kota Surabaya. Kegiatan pengajian ada dua yakni untuk bapak-bapak dan juga ibu-ibu. Mayoritas ibu-ibu rumah tangga keluarga miskin di kelurahan Wonokusumo ini mengikuti kegiatan pengajian. Namun ada beberapa yang tidak mengikuti atau dalam satu keluarga hanya salah satu yang mengikuti pengajian, ibu-ibu atau bapak-bapak. Hal ini berkenaan dengan kemampuan pembayaran arisan pada pengajian. Pengajian tidak hanya sebagai penambah pengetahuan agama, pembacaan ayat-ayat maupun silaturahmi namun kegiatan tersebut juga dibuat semacam arisan. Arisan pengajian ini bisa dijadikan sebagai tabungan oleh ibu-ibu rumah tangga miskin karena mereka akan mendapatkan uang tambahan yang telah dikumpulkannya setiap minggu atau bulan. Setiap pertemuan mereka membayar arisan Rp. 10.000-Rp. 20.000.

Dalam kegiatan politik, keluarga miskin hanya dilibatkan pada saat pencoblosan atau pemilu saja. Mereka tidak diberikan akses dan manfaat terkait dengan pendidikan, sosialisasi maupun kegiatan politik lainnya (Wahyu, 2017). Mereka hanya diambil suara saat pemilu tanpa dilibatkan dalam proses pengambilan kebijakan dan program-program terutama berkenaan dengan program pengentasan kemiskinan. Berdasarkan hasil wawancara dengan beberapa informan, keluarga miskin terutama ibu-ibu rumah tangga miskin di kelurahan Wonokusumo kecamatan Semampir kota Surabaya menjadi pragmatis dalam kegiatan politik. Mereka melakukan pencoblosan atau menggunakan hak pilihnya ketika ada uang atau bantuan yang mereka terima. Jika mereka tidak mendapatkan amplop, mereka cenderung untuk tidak menggunakan hak suaranya. Mereka agak kecewa dengan politik, mereka tidak diberikan akses, kesempatan dan bantuan untuk keluar dari kemiskinan yang mereka hadapi. Mereka sadar bahwa mereka hanya dijadikan alat atau objek saat pemilu diadakan. Oleh karena itu mereka cenderung bersikap apatis, pesimis dan pragmatis.

\section{Daya Lenting Ibu Rumah Tangga Pada Keluarga Miskin Di Kota Surabaya}

Pada dasarnya, keluarga miskin hidup dalam kondisi yang serba terbatas. Berbagai macam kesulitan sering terjadi dalam kehidupannya bahkan hanya untuk memenuhi kebutuhan sehari-hari. Ibu rumah tangga adalah perempuan yang paling 
rentan dalam kondisi seperti ini. Ibu rumah tangga harus memutar otak untuk mencari tambahan uang dari penghasilan suaminya, menyesuaikan penghasilan dengan kebutuhan yang harus dipenuhi dan kondisi-kondisi krisis lainnya. Setiap hari mereka berada kondisi yang rentan, rentan terhadap segala sesuatu yang dapat mengguncang hidupnya. Namun mereka berhasil untuk bertahan di tengah kehidupan yang serba terbatas. Kemampuan perempuan untuk menyesuaikan diri atau beradaptasi agar mampu bertahan hidup disebut dengan daya lenting. Daya lenting atau ketahanan perempuan adalah kemampuan perempuan untuk mengatasi, menyesuaikan diri. (adaptasi) dengan kondisi yang sulit kemudian bisa bangkit kembali dari kondisi terpuruk (Reivich \& Shatte, 2002). Daya lenting ibu rumah tangga pada keluarga miskin di kelurahan Wonokusumo kecamatan Semampir kota Surabaya adalah dengan melakukan berbagai cara atau opsi sesuai dengan kondisi yang mereka hadapi. Caracara yang dilakukan oleh ibu rumah tangga pada keluarga miskin adalah mulai dari menghemat, menjual barang atau menggadaikannya dan meminjam uang. Secara berurutan akan dijelaskan.

\section{Menghemat dengan Mengencangkan "lkat Pinggang"}

Dalam keadaan normal, tidak mengalami goncangan, warga miskin di kelurahan Wonokusumo kecamatan Semampir kota Surabaya mengalami kekurangan bahkan mengatur pola makannya. Pengaturan pola makan bukan bertujuan untuk diet atau untuk hidup sehat namun mereka mengatur pola makan agar makanan yang ada cukup untuk dimakan oleh seluruh keluarga. Penghasilan yang didapat suami tidak menentu karena pekerjaan mereka serabutan. Ibu rumah tangga yang tidak bekerja semakin sulit untuk mengatur keuangan dan menyediakan makanan bagi keluarganya karena hanya mengandalkan pendapatan suaminya saja. Ibu rumah tangga yang berpenghasilan atau bekerja pada keluarga miskin, bisa sedikit bernafas karena mereka memiliki uang tambahan untuk memenuhi kebutuhan keluarganya. Keluarga miskin yang suami dan istrinya bekerja bisa mendapatkan uang tidak hanya dari suaminya, ibu rumah tangga berkonstribusi dalam pemenuhan kebutuhan keluarganya.

Peran ibu rumah tangga juga penting dalam melakukan pengaturan pola makan keluarga. lbu rumah tangga keluarga miskin harus menggunakan uang yang ada untuk membeli dan memasak makanan yang cukup untuk semua keluarga. Ibu rumah tangga keluarga miskin harus bisa hidup hemat, mengatur pengeluaran bahkan mengencangkan ikat pinggangnya agar anak-anak bisa kenyang. Kemiskinan membuat anak-anak dan perempuan menjadi korban dan mereka adalah orang yang paling rentan terkena dampaknya. Hidup hemat adalah salah satu cara atau strategi yang dilakukan oleh ibu rumah tangga keluarga miskin untuk tetap bertahan hidup. Cara ini merupakan cara yang telah umum dilakukan oleh semua keluarga yang mengalami kesulitan terutama keluarga miskin (Subair, 2012). Cara ini juga dilakukan oleh keluarga miskin yang ada di wilayah perkotaan. Scott mengatakan bahwa cara untuk bertahan hidup keluarga miskin dengan cara mengurangi pengeluaran atau dengan cara menurunkan kualitas makanan yang dikonsumsinya (Scott, 2019).

\section{Menjual Barang-barang atau Menggadaikannya}

Dalam kondisi darurat atau terjepit, barang-barang berharga yang bisa mendatangkan uang dijual atau digadaikan oleh keluarga miskin. Alternatif menjual atau menggadaikan suatu barang ini dipilih oleh ibu rumah tangga keluarga miskin jika mereka tidak mendapatkan pinjaman dari tetangga maupun saudara. Ada beberapa 
barang elektronik, kendaraan bermotor maupun perhiasan yang mereka miliki dapat dijual atau digadaikan. Biasanya mereka memilih untuk menjual jika uang yang mereka perlukan banyak dan mereka tidak mempunyai daya untuk menebus kembali barang tersebut. Jika uang yang diperlukan sedikit dan cicilan bunga serta barang tersebut bisa ditebus maka mereka memilih untuk menggadaikannya. Ibu rumah tangga pada keluarga miskin harus mampu memprediksi dan mengkalkulasi kebutuhan, keuangan dan kemampuan diri agar mereka terus bertahan dan bangkit kembali.

\section{Meminjam Uang Kepada Tetangga/Saudara/Bank}

Kerentanan dan ketidakberdayaan keluarga miskin di wilayah perkotaan khususnya di kelurahan Wonokusumo kecamatan Semampir kota Surabaya, menyebabkan ibu rumah tangga keluarga miskin mencari jalan alternatif untuk memenuhi kebutuhannya. Kebutuhan subsisten hanya untuk sekedar makan saja, mereka sudah kesusahan. Terkadang apa yang mereka dapatkan hari ini hanya bisa digunakan untuk makan hari itu juga. Untuk kebutuhan darurat, pada saat anak sakit atau anak sedang ada kebutuhan sekolahnya, mereka kebingungan untuk melakukan pembayaran. Salah satu alternatif yang dilakukannya adalah dengan meminjam uang kepada tetangga, saudara dan bank.

Tabel 1. Urutan Katup Penyelamat bagi Keluarga Perempuan Miskin di Kota Surabaya

\begin{tabular}{lll}
\hline No & Katup Penyelamat & Alasan Pemilihan Katup Penyelamat \\
\hline 1 & Tetangga & Orang terdekat keluarga perempuan miskin yang sedang \\
& dalam perantauan, hidup bersama, memiliki nasib yang \\
& sama baik dari segi ekonomi, psikologis maupun \\
& kesukuan (primordial). Memiliki kondisi yang serba sulit \\
& dan kekurangan serta merasa sebagai saudara di tanah \\
& rantau dengan suku yang sama (suku madura), mereka \\
& memiliki perasaan senasib. \\
\hline 2 Saudara & Orang yang bertindak sebagai penolong di masa-masa \\
& krisis setelah tetangga. Ada beberapa saudara yang juga \\
& bekerja di Surabaya, keluarga perempuan miskin akan \\
& lebih cepat meminta pertolongan kepada saudara di \\
& sana. Namun jika mereka tidak memiliki saudara yang \\
& jaraknya dekat maka mereka akan meminta pertolongan \\
& pada saudara yang jauh. Oleh karena itu keluarga \\
& perempuan miskin akan lebih dahulu meminta \\
& pertolongan pada tetangga, yang jaraknya lebih dekat. \\
& Alternatif terakhir untuk mendapatkan pinjaman uang \\
& adalah dengan meminjam pada pihak perbankan. Namun \\
& hal itu jarang sekali mereka lakukan karena pihak \\
& perbankan sulit memberikan pinjaman pada mereka. \\
& Mereka tidak memiliki jaminan dan kredibilitas untuk \\
& menjadi calon peminjam modal dipertanyakan. Prosedur \\
& administrasi yang rumit menyebabkan keluarga miskin di \\
& perkotan jarang sekali meminjam uang pada pihak \\
& perbankan.
\end{tabular}

Sumber: Hasil olah data berdasarkan wawancara pada beberapa informan 
Keluarga miskin yang tinggal di kelurahan Wonokusumo kecamatan Semampir kota Surabaya adalah para perantau yang tinggal jauh dari keluarga, orang terdekat yang bisa menjadi katup penyelamat adalah tetangganya. Katup penyelamat keluarga miskin di perkotaan dengan masyarakat nelayan dan pertanian memiliki perbedaan. Jika pada masyarakat pertanian dan pesisir, katup penyelamat keluarga miskin adalah saudara, patron dan tetangga. Urutan pertama yang menjadi katup penyelamat bagi keluarga miskin pada masyarakat pertanian dan pesisir adalah saudara, patron kemudian tetangga (Elanda \& Alie, 2020). Urutan katup penyelamat keluarga miskin di perkotaan adalah tetangga dan saudara (lihat tabel 1).

\section{Mengandalkan Uang Arisan}

Keluarga miskin di kawasan urban memiliki ikatan solidaritas yang cukup kuat. Mereka mengadakan kegiatan pengajian dengan sistem arisan. Selain untuk menyambung tali silaturahmi dan mengikat tali persaudaraan diantara tetangga, mereka juga memiliki tabungan dalam bentuk uang arisan. Uang ini bisa diandalkan untuk memenuhi kebutuhan-kebutuhan sekunder, misalnya membeli perhiasan, barangbarang elektronik dan menambah modal usaha. Baik dalam pengajian bapak-bapak maupun ibu-ibu, terdapat arisan yang mereka kumpulkan setiap bulan atau setiap minggunya. Setiap minggu atau bulan mereka hanya membayar uang arisan sebanyak Rp. 10.000-Rp. 20.000. Setiap minggu atau bulan juga mereka melakukan undian untuk menentukan pemenangnya atau yang mendapatkan arisan.

Uang arisan tersebut sebetulnya adalah uang yang terkumpul dari setiap kali membayar arisan tiap bulan atau tiap minggu. Uang arisan ini diibaratkan uang tabungan untuk membeli barang-barang yang mereka inginkan. Peran ibu rumah tangga keluarga miskin penting dalam mengelola keuangan. Ibu rumah tangga keluarga miskin di kelurahan Wonokusmo kecamatan Semampir kota Surabaya memanfaatkan hasil arisan untuk membeli barang-barang yang memiliki nilai ekonomis seperti barang-barang elektronik maupun perhiasan. Barang-barang ini diibaratkan seperti tabungan, jika dalam kondisi darurat, barang-barang tersebut bisa dijual atau digadaikan. Selain itu, ada juga ibu rumah tangga keluarga miskin memanfatkan uang arisan sebagai modal usaha atau menambah modal usaha yang telah mereka lakukan.

\section{Berjualan}

Para suami atau kepala rumah tangga pada keluarga miskin di kelurahan Wonokusumo kecamatan Semampir kota Surabaya bekerja sebagai kuli bangunan, serabutan dan petugas kebersihan. Penghasilan yang tidak menentu, penghasilan yang kecil dan pekerjaan yang tidak menetap membuat perempuan menyiasati kondisi tersebut dengan berjualan. Ibu rumah tangga keluarga miskin berjualan gorengan, minuman, makanan ringan dan bubur untuk mendapatkan penghasilan tambahan. Berjualan makanan dan minuman tersebut memerlukan modal yang sedikit dan digemari oleh banyak orang. Selain itu, alasan memilih jualan gorengan adalah jika tidak laku makanan tersebut bisa dijadikan lauk atau makanan bagi keluarganya. Oleh karena itu, ibu rumah tangga pada keluarga miskin memilih usaha tersebut.

Daya lenting perempuan terletak pada keuletan seorang ibu rumah tangga keluarga miskin untuk selalu mencari cara agar mereka bertahan dan bangkit dari keterpurukan. Mereka menyisihkan sedikit demi sedikit uang belanja untuk mengumpulkan modal jualan. Mereka juga berkorban untuk mengemban beban ganda yang harus dipikulnya. Para ibu rumah tangga keluarga miskin tidak kenal lelah untuk

$$
\text { Jurnal Sosiologi Pendidikan Humanis } 211 \text { | } 215
$$


terus mengerjakan pekerjaan domestik dan publik dalam satu waktu (bersamaan). Mereka masih menjalankan tugas domestiknya sebagai seorang istri dan ibu, bahkan saat berjualan mereka sambil mengasuh anaknya. Dalam keluarga miskin, para ibu rumah tangga tidak bisa bekerja untuk meninggalkan rumahnya apalagi jika mereka memiliki anak yang masih kecil. Hal terbesar yang menghambat mereka untuk bekerja di luar rumah adalah tugas domestiknya. Mereka tidak diijinkan oleh suaminya untuk meninggalkan tugas domestiknya yaitu mengurus anak. Pada kasus ini, dapat terlihat bahwa opresi pada ibu rumah tangga keluarga miskin sangat tinggi. Mereka mengalami proses pemiskinan atau feminisasi secara struktural.

\section{KESIMPULAN}

Kemiskinan di kota Surabaya tidak hanya disebabkan oleh over urbanization saja. Ada faktor-faktor lain yang turut menyebabkan masalah kemiskinan menjadi kompleks untuk dikaji terlebih mengenai jumlah angka kemiskinan yang banyak didera oleh perempuan. Data menunjukkan jumlah perempuan bekerja mulai ada peningkatan dan kontribusi perempuan dalam penguatan ketahanan ekonomi keluarga juga sudah diakui. Namun proses pemiskinan atau feminisasi kemiskinan masih saja terjadi. Perempuan tidak dilibatkan dalam pengambilan keputusan, dibebani oleh tanggung jawab domestik yang itu sebetulnya bisa dipertukarkan, tidak diberikan kesempatan untuk meningkatkan kapabilitas baik melalui pendidikan formal maupun pelatihan informal. lbu rumah tangga pada keluarga miskin di kelurahan Wonokusumo kecamatan Semampir kota Surabaya mengalami opresi bertubi-tubi. Mereka mengalami kerentanan, ketidakadilan, kemiskinan dan ketidakberdayaan dalam hidupnya. Mereka seolah sengaja dimiskinkan oleh budaya patriarkhi yang tidak memberikan ruang bagi perempuan untuk berakselerasi.

Di tengah kondisi ketidakberdayaan, ketidakadilan dan kerentanan ibu rumah tangga keluarga miskin mencoba untuk mencari jalan keluar, beradaptasi dan bangkit kembali. Usaha-usaha yang dilakukan oleh ibu rumah tangga keluarga miskin ini disebut sebagai daya lenting. Daya lenting yang menjadi strategi ibu rumah tangga keluarga miskin untuk bertahan hidup adalah dengan cara mengencangkan ikat pinggang (hidup berhemat), berjualan, mengikuti arisan, meminjam uang kepada tetangga, saudara dan perbankan serta menjual tau menggadaikan barang-barangnya. Tidaklah mudah bagi ibu rumah tangga keluarga miskin untuk tetap bertahan di tengah keterbatasan, namun mereka mampu bertahan dengan cara-cara yang mereka gunakan. Daya lenting yang dilakukan oleh ibu rumah tangga miskin penuh dengan kehati-hatian dalam mengelola keuangan, kebutuhan dan menyiasati pengeluaran. Cara mereka untuk memilih strategi dalam melakukan penghematan, arisan, penjualan/penggadaian barang, meminjam uang dan berjualan berdasarkan pada kemampuan mereka untuk mengkalkulasi kemungkinan-kemungkinan buruk yang akan terjadi.

\section{DAFTAR PUSTAKA}

Ariadi, S., \& Suyanto, B. (2009). Studi tentang Ketidakberdayaan Perempuan dan Anak dalam Keluarga Miskin di Perkotaan. Universitas Airlangga Press.

Asyifani, K. (2021). Solidaritas Sosial dalam Marginalisasi Masyarakat Miskin (Studi di Dusun Kentheng Kota Surakarta). Jurnal Dimensia, 10(1). https://doi.org/10.21831/dimensia.v10i1.41052

Badan Pusat Statistik. (2018). Survei Angkatan Kerja Nasional. https://www.bps.go.id/publication/2018/11/30/6d8a8eb26ac657f7bd170fca/keadaa 
n-angkatan-kerja-di-indonesia-agustus-2018.html

Basir, M. (2012). Hubungan Sosial dan Akses Masyarakat pada Lingkungan Pemukiman Kumuh di Kota Makassar. Jurnal Perkotaan, 4(1). http://ojs.atmajaya.ac.id/index.php/dululppm/article/view/83

Biro Pusat Statistik. (2015). Surabaya Dalam Angka. https://surabayakota.bps.go.id/publication

Butar, C. D., \& Setiawan, P. R. (2012). Penataan Lingkungan Kumuh di Wilayah Kecamatan Semampir Kota Surabaya Melalui Pendekatan Patisipasi Masyarakat. Jurnal Teknik Pomits, 1(1). http://digilib.its.ac.id/public/ITS-paper-267983608100038-Paper.pdf

Creswell, J. W. (2017). Research Design: Qualitative, Quantitative, and Mixed Methods Approaches. Sage publication.

Darma, P. M., \& Khambali, S. (2013). Hubungan Antara Komponen Rumah Dengan Kejadian Penyakit ISPA di Wilayah Kerja Puskesmas Wonokusumo Surabaya. Jurnal Gema Kesehatan Lingkungan, 11(3).

Elanda, Y., \& Alie, A. (2020). Strategi Masyarakat Nelayan dalam Pemenuhan Kebutuhan Subsistennya di Desa Wisata Pasir Putih Dalegan Gresik. Journal Of Urban Sociology, 3(2). http://dx.doi.org/10.30742/jus.v3i2.1234

Elviani, D. (2017). Dampak Sosial Program Campus Social Responsibility di Kecamatan Semampir Kota Surabaya. https://repository.unair.ac.id/67776/3/Sec.pdf

Fakih, M. (2016). Analisis Gender dan Transformasi Sosial. Insist Press.

Jellinek, L. (1995). Seperti Roda Berputar. LP3ES.

Kementrian Pemberdayaan Perempuan dan Perlindungan Anak. (2019). Kementrian Pemberdayaan Perempuan dan Perlindungan Anak. https://www.kemenpppa.go.id/lib/uploads/list/b4bdc-profil-perempuan-indonesial2019.pdf

Lembaga Penelitian Smeru Reseach Institute. (2012). Mengintegrasikan Aspek Spasial Kemiskinan ke dalam Perencanaan Spasial Perkotaan: Solusi untuk Mengatasi Masalah Kemiskinan. http://smeru.or.id/sites/default/files/publication/urbanpoverty_pb_ind_0.pdf

Noerdin, E. (2006). Potret Kemiskinan Perempuan. Women Reseach Institute.

Ollenburger, C. J., \& Moore, A. H. (2002). Sosiologi Wanita. Rineka Cipta.

Profil Wonosari Wetan Kelurahan Wonokusumo. (n.d.). Retrieved November 13, 2020, from http://digilib.uinsby.ac.id/129/6/Bab 4.pdf

Rachmawati, N. (2011). Budaya Kemiskinan Masyarakat Kota. Jurnal Industri Dan Perkotaan, 16(27). https://jip.ejournal.unri.ac.id/index.php/JIP/article/download/5762/5325

Rasna, \& Hidaya, N. (2019). Eksistensi Perempuan dalam Transformasi Sosial (Studi di PT Multi Usaha Raya Kabupaten Sorong). Jurnal Noken IImu-IImu Sosial, 5(1). https://doi.org/10.33506/jn.v5i1.761

Reivich, K., \& Shatte, A. (2002). The Resiliance Facto: 7 Essential Skill for Overcoming Life's in Inevitable Obctacles. Broadway Books.

Ritonga, R. (2014). Kebutuhan Data Ketenagakerjaan untuk Pembangunan Berkelanjutan. Biro Pusat Statistik.

Riyanta, O. R., \& Murtedjo. (2019). Kajian Kondisi Sosial Ekonomi Migran Madura Masuk di Kelurahan Tanah Kali Kedinding Kecamatan Kenjeran Kota Surabaya. Swara Bhumi, 1(1). https://jurnalmahasiswa.unesa.ac.id/index.php/swarabhumi/article/view/26887

Rustanto, B. (2015). Menangani Kemiskinan,. PT Remaja Rosdakarya.

Sach, J. D. (2005). The End of Proverty: Economic Possiblelities for Our Time. Penguin Press.

Scott, J. (2019). Moral Ekonomi Petani. LP3ES.

Setijaningrum, E. (2012). Pengembangan Model Pemberdayaan Masyarakat sebagai Upaya Pengentasan Kemiskinan di Perkotaan. Jurnal Masyarakat Kebudayaan 
Dan Politik, 25(2).

Subair, N. (2012). Perangkap Kemiskinan dan Strategi Bertahan Hidup Perempuan Miskin. Universitas Makassar.

Suparlan, P. (1984). Kemiskinan di Perkotaan. Yayasan Obor Indonesia.

Suryawati, C. (2005). Memahami Kemiskinan Secara Multidimensional. JMPK, 8(3). https://media.neliti.com/media/publications/22327-ID-memahami-kemiskinansecara-multidimensional.pdf

Syahra, R. (2003). Modal Sosial, Konsep dan Aplikasi. Jurnal Masyarakat Dan Budaya, 5(1). https://jmb.lipi.go.id/jmb/article/download/256/234/497

Todaro, M. P. (2000). Pembangunan Ekonomi,. Bumi Aksara.

Trisnawaty, S. (2018). Analisis tentang Kemiskinan Berdasarkan Persepsi Orang Miskin dan Pemerintah. Jurnal IImu Ekonomi Mulawarman, 2(4). http://dx.doi.org/10.29264/jiem.v2i4.2457

Utamaningsih, A. (2020). Feminisasi Kemiskinan dan Pemberdayaan Perempuan Berperspektif Sosiopsikologis. UB Press.

Utomo, S. K., \& Haryani, T. N. (2019). Mengurai Kemiskinan Kepala Rumah Tangga Perempuan,. Jurnal Komunikasi Dan Kajian Media, 3(1), 15-23. http://dx.doi.org/10.31002/jkkm.v3i1.1331.

Wahyu, G. W. (2017). Pola Partisipasi Politik Masyarakat Miskin Kota: Studi Kasus Masyarakat Miskin di Kelurahan Tanah Tinggi, Jakarta Pusat. Universitas Negeri Yogyakarta. 
Jurnal Sosiologi Pendidikan Humanis 215|215 